\title{
Human rights abuses at the Rio 2016 Olympics: activism and the media
}

\author{
Journal: Leisure Studies
}

Authors

Adam Talbot (Corresponding Author), School of Sport and Service Management, University of Brighton

School of Sport and Service Management, Darley Road, Eastbourne, BN20 7UR

$+447929625326$

A.Talbot@brighton.ac.uk

Thomas F. Carter, School of Sport and Service Management, University of Brighton

School of Sport and Service Management, Gaudick Road, Eastbourne, BN20 7SR

$+441273641852$

\section{T.F.Carter@brighton.ac.uk}

\section{Acknowledgements}

The support of Catalytic Communities was invaluable during the execution of fieldwork. In particular, Cerianne Robertson was a crucial sounding board for the ideas discussed in this article, and oversaw the Favelas in the Media research project mentioned in this article. Thanks must also go to all the residents of Vila Autódromo and other activists in Rio for their willingness to share their stories, and for their endless determination and kindness. Finally, we wish to thank the two anonymous reviewers for their insightful and constructive comments which aided the development of this article.

\section{Abstract}

This article examines activists' use of human rights as a discourse to contest the impacts of the Rio 2016 Olympic Games by drawing on a wider ethnographic project examining activism at Rio 2016. Focussing on two areas of contention, forced evictions and police brutality, the article considers the way activists framed their grievances and how mainstream international media outlets reported those grievances. While activists fighting against forced evictions explicitly used the language of rights in their activism, media accounts tended not to discuss these issues using this lexicon. Conversely, grassroots activists protesting around the issue of police brutality did not tend to frame their grievances in terms of rights, but these issues were discussed as human rights abuses in the media. This points to a dual role played by activists fighting forced evictions: while they are fighting to keep their own homes, they are also part of a wider discursive battle for the right to housing to be recognised and respected.

Keywords: mega-events, Olympics, Rio de Janeiro, activism, media, human rights 


\section{Introduction}

The Olympic Games and other mega-events have had allegations of human rights abuses levelled at their organizers in recent decades, which are at odds with the Olympic rhetoric of peace and universalism. Through the militarisation of public space, forced removals, intimidation of political activists and police brutality, the world's premier sporting event has gained an embarrassing reputation for disregarding host populations (Lenskyj, 2008). These tactics have been particularly damaging following the recent trend of hosting mega-events in the 'developing world', where there tends to be greater potential to harm the marginalised urban poor. While such tactics are particularly worrisome in autocratic states, such as Russia and China, Rio's Olympic dream also came with more than its fair share of controversies, particularly related to the (in)famous favela communities around the city, despite the city and nation's democratic governance.

In response, activists in host cities have resisted the Olympics and elements of urban restructuring they bring. From Vancouver, through London, to Sochi, anti-Olympic protest was the norm well before the Olympics touched down in Rio de Janeiro (Boykoff, 2014). These activists were often supported by international human rights organizations, such as Amnesty International and Human Rights Watch. Various diverse grassroots groups campaigned against human rights abuses in the lead up to the 2016 Olympic Games. Many of these groups used the language of human rights to frame their critiques of the restructuring of the city that came with the Olympics. The Comitê Popular da Copa e Olimpíadas (Popular Committee for the World Cup and Olympics ${ }^{1}$ ) was formed specifically to protest around issues associated with mega-events, and produced several detailed dossiers of what they described as human rights abuses related to such events. Others groups protested around diverse issues such as police violence, housing rights, and environmental damage also took issue with the Olympics, claiming rights were violated and eroded by the mega-event.

This article discusses grassroots activism against human rights abuses at the 2016 Olympic Games, hosted in Rio in August 2016. Drawing on ethnographic fieldwork conducted in the year prior to the Games, it examines how various groups constructed their grievances in terms of human rights abuses in the lead up to the mega-event. The focus is on two areas of contention: forced removals and police violence. Grassroots responses to these abuses are detailed and compared, including levels of media attention and support from international human rights NGOs.

\section{Rights in Rio}

Grassroots protests over alleged denials of human rights or the suffering of abuse as a result of mega-events happening in their city are an increasingly prominent and common form of activism. The deployment of human rights discourses and the various claims made regarding potential violations are in many ways as competitive as the contests occurring within the athletic arenas during the Games. These competitions rest upon competing interpretations and assertions of what human rights are and the ways in which those rights are recognized and deployed. At stake here are a set of questions, some of which the very idea of human rights rest upon. The two points around which the question of rights is invoked are violence directed at citizens in the form of (un)lawful police violence and violence destroying citizens' property and denial of adequate housing. In each case, a central point to these discourses is the role of the Brazilian state in defining who is and is not a "person".

\footnotetext{
${ }^{1}$ All translations are by the first author
} 
Contrary to Hobbes (1962[1651]) and Paine (1993[1791]), rights, including human rights, are not an inherent quality of human beings; rather they are negotiated and contested conditions of being. Nonetheless, the idea that human rights are inalienable remains a powerful symbolic tool for driving mobilisation rather than as a legal instrument (Schiengold, 2004). Yet the paradox of institutionalisation, whereby "once institutionalised, human rights stand in a complex and ambiguous relation to power" (Stammers, 2009, p. 129), means that the ability to mobilise the discourse of rights towards meaningful social change can also serve or sustain those in power. With regard to the right to housing, "claiming a right to housing can be a demand for profound social change... to reconstruct the terms of legitimate authority through political action" (Hoover, 2015, p. 1095).

Although The Universal Declaration of Human Rights asserts the inalienable rights of all human beings, the power of the Declaration rests on the sovereignty of its signatory states, as it acknowledges in passing in its Introduction. Human rights and sovereignty are not "mutually antagonistic international regimes" but are "two normative elements of the inherently contradictory modern discourse of legitimate statehood" (Reus-Smit 2001: 536-7). Human rights, then, are inextricably tied to nation-states in which personhood is both conferred and revoked by sovereign leaders. The role of the state in the recognition, implementation, and bestowing of rights is a central aspect of personhood. Personhood may include many, although not all, adult humans and, in law, it also includes corporations and ships. The legal construction of rights is highly volatile: individual subjectivity can be given and taken away and there is no guarantee that one's "natural" existence and the legal human code will coincide. It is not so much that persons have rights but that rights make persons (Arendt 1973, p. 279-280).

Although Brazilian law is based on liberal and democratic principles of universalism and equality, historically its practice has often diverged from theory and tended to be applied in a rigorous way only to the masses. The vulnerable, such as those who lack adequate housing, the marginalized, and the impoverished, depend on rights more than ever yet their very marginality transforms them into easily exploitable subjects not due full consideration under the "human" part of human rights. "The so-called sacred and inalienable rights of man show themselves to lack every protection and reality at the moment in which they can no longer take the form of rights belonging to citizens of a state" (Agamben, 2008, p. 126).

In Brazil, universal laws have been used to simultaneously liberate and exploit different segments of the populace (DaMatta, 1984). These resulting decades-long practices created "differentiated citizenship" (Holston 2008) whereby rights are applied differently to different sectors of Brazilian society, including the very recognition of a "person". The progressive wing of the Catholic Church and leftist political parties in the late 1970s and early 1980s challenged these practices by initiating the first discourses of human rights in Brazil (Caldeira 2000). Powerful right-wing politicians subverted this human rights discourse into practices that provided "special favours", dispensations, and privileges for criminals that both preyed upon the urban poor's fears of violence while simultaneously labelling favela residents as criminal themselves.

The use of human rights discourse against marginalized populations in Brazil coincides with statesanctioned violence against the poor - a practice that continued in the ramp up to the various megaevents that have occurred in Rio over the past decade. A hangover from the military dictatorship of 1964-1985, Brazil's military police takes a "shoot first, ask questions later" approach to law enforcement (Amnesty International, 2015). Police killed around 2,500 people in the city of Rio de Janeiro in preparation for the 2016 Olympic Games (Amnesty International, 2016b). While many of these killings would have involved a legitimate use of force, others were extrajudicial executions 
(Human Rights Watch, 2016), and according to Amnesty International (2016a, p. 92), "police responsible for unlawful killings enjoyed almost total impunity". Police regularly covered up their actions, planting drugs and weapons on corpses, and undertook revenge-killing sprees when police officers had been killed (Human Rights Watch, 2016). The high stress placed on officers working in the favela pacification programme (to be discussed in more detail shortly), coupled with the lack of a sufficient support network means police are almost seven times more likely to commit suicide than the state average (Fábio, 2016).

Favela residents' experiences of state-based violence exemplifies the simple fact that human rights can exclude the most vulnerable people in a society. Whether these are refugees in camps populous enough to be medium-sized cities that do not exist on any official map (Rawlence, 2016) or the impoverished citizens of a state, "the rhetoric of rights does little to address the causes of oppression, such as material inequality and exploitative practices" (Bourke, 2011, p. 162). The central problem is the refusal of the wealthy to provide meaningful assistance, let alone adopt policies of redistribution. The question of rights, the definition of what rights are, and who is entitled to have them sits at the centre of the arrival of any Olympic spectacle.

Much has been written about the triumphs of some Olympic cities and the financial follies of others. With each Olympiad, city officials become ever more preoccupied with the indelible mark "The Games" might leave on housing stock and transportation infrastructure, on recreational and cultural amenities, and on the reputation of the city as "world class" (Gold and Gold, 2011). The litany of Olympic lowlights underscores that no Olympic city has escaped the travails of housing displacement (COHRE 2007). The housing displacement that precedes and makes possible the construction of an athletes' village, new natatorium, or signature stadium has direct and profound impact upon local communities well before the arrival of the Olympic torch and for years afterward. The Olympics bring with them a range of pressures on local housing, from direct forced eviction to accelerated patterns of gentrification. More than two million residents, mostly poor, were displaced by Olympic development in the past two decades, and the London Olympic Authority also displaced whole neighbourhoods as part the broader urban regeneration plan tied to hosting the 2012 Olympiad (Davis and Thornley, 2010; Vijay, 2015). The invocation of human rights over housing, the use of urban space, and the ongoing contest over the redevelopment of Rio (Faulhaber, 2013; Perlman, 2010) clearly is the status quo of Olympic development.

The assertion that the right to housing is a human right rests on one article in the Universal Declaration of Human Rights. Article 25 of the Declaration is the only place in the entire document where housing is explicitly mentioned as a right. It states,

Everyone has the right to a standard of living adequate for the health and well-being of himself and of his family, including food, clothing, housing and medical care and necessary social services, and the right to security in the event of unemployment, sickness, disability, widowhood, old age or other lack of livelihood in circumstances beyond his control (United Nations, 1948).

Article 12 of the Declaration also includes implicit protection against the seizure and destruction of private property. It states,

No one shall be subjected to arbitrary interference with his privacy, family, home or correspondence, nor to attacks upon his honour and reputation. Everyone has the right to the protection of the law against such interference or attacks (United Nations, 1948). 
Historically, the right to housing for residents of Brazil's favelas has not been respected, with evictions often seen as the solution to the apparent 'problem' of favelas (Faulhaber and Azavedo, 2015). Favelas are self-organized neighbourhoods that emerged from an unmet need for housing when residents took their situation into their own hands and built their own communities. Yet these communities are often stigmatised as havens of criminality and poverty, such that removal is seen as the best option for favelas residents. The organic development of favelas means their legal status (in terms of property rights) differs from favela to favela - and even from house to house. For many years, this precariousness resulted in numerous evictions, under both military and democratic governments. However Article Six of the 1988 constitution, written from scratch after the end of the military regime (1964-1985), guaranteed the right to housing as a social right for all Brazilians (Constitução Federal, 1988) and the sheer power of voter numbers in favelas made large-scale removal politically unrealistic (Perlman, 2010). The 1988 constitution is a key discursive tool for activists claiming the right to housing as, alongside legislation ensuring that property must have a social function, it empowers activists claiming their land as their right (Earle, 2012).

The chief problem with conferring rights, such as the right to housing, is a fundamental one for it merely shores up an already difficult and tenuous notion of exactly what it means to be "human", for rights are not absolute and do not exist in a vacuum (Douzinas, 2000). Assigning rights to one party creates obligations for other parties. Rights and the assertion of rights politicises certain issues; asserting a right to housing politicises land ownership, for example. While rights may operate in an indisputable force of emancipation at one moment in history, they may become at another time a regulatory discourse, a means of obstructing or co-opting more radical political demands or simply the most hollow of empty promises (Brown 1995, p. 98-99). It is this dynamic that this article examines media attention to the grassroots activism taking place in Rio in the build up to the 2016 Olympic Games.

Activists in Rio claimed many things as "rights abuses", from environmental damage and evictions to police violence and child sex trafficking. Activists organising around these issues were also engaged in a struggle for personhood, over the right to a right (Arendt 1973). Looking at media coverage helps to understand which of these claims gains traction, with some claims reported as rights abuses and others not. Research into international media coverage of Rio's favelas undertaken by Catalytic Communities (2015) shows that issues related to policing, security and pacification were discussed in terms of rights more often than issues related to housing, such as evictions and gentrification.

Figure 1: media coverage of police brutality and housing issues

As Figure 1 shows, a significant amount of media attention was drawn to issues related to police brutality. More illuminatingly, when looking only at articles that also mentioned human rights, the percentage of articles discussing these issues increased sharply, roughly doubling for each issue. This is particularly noteworthy as a significant amount of articles produced in the lead-up to the Olympics on Pacification, Security and Policing discussed security for Olympic athletes and tourists, paying little attention to the impact on residents. Conversely, housing issues - which drew less media attention generally - tended to stay around the same percentage when comparing between all articles published and those that discussed human rights.

\section{Methodology}

Looking at media resources isn't adequate to capture the experiences of marginalised populations in Rio de Janeiro. While indicative (to an extent) of public opinion, the presence of bias in media coverage is well known, not just in terms of the content but also in relation to what is and isn't 
reported (Hannerz 2004, Whannel 1992). A deeper level of insight is required to accurately assess the nature of rights in the Olympic city along the lines of Boykoff's work (2014),. As such, this article is based upon an ethnographic research project examining activists' practices in the run up to the 2016 Olympic Games. Ethnography allowed the researcher to gain a deep empathetic understanding of activists' lifeworlds (Emerson, Fretz and Shaw, 2001). Fieldwork was undertaken in Rio de Janeiro by the first author from September 2015 to September 2016, a period culminating with the Olympic Games in August 2016.

This fieldwork, however, did not mirror other ethnographers' work in Rio's favelas (Scheper-Hughes, 1993; Goldstein, 2003; Larkins, 2015) in that the researcher did not live in a favela. This decision was taken for two specific reasons. One, given the precarious and emotional question of the favela's very survival, we felt that it would be inappropriate to take up housing space there. Two, the object of enquiry was not the everyday lives of Vila Autódromo residents but activists' political activities. Through participant observation with several activist groups and the residents of Vila Autódromo, the first author witnessed alleged abuses of human rights first hand. These groups used different methods, including protest marches, online publishing, public meetings, and the production of dossiers, to highlight these abuses and make claims about the nature of rights. As part of the fieldwork, the first author attended public and closed meetings, worked on planning actions, discussing strategies for engagement and produced and translated published documents for activist groups. The first author also observed residents' protests, chronicled demolitions, and assisted journalists on site. While fieldwork focussed primarily on housing issues in the favela located next to the Olympic park, data was also collected on other contentious issues across the city, including a significant amount of data on police violence. Field data was recorded in a field diary and complemented by photographs taken and activist materials collected at protest events.

Not being Brazilian, the first author learnt both the Portuguese language and various cultural codes throughout his fieldwork. His constant bridging between British/Brazilian worldviews within a pluralized singularity of the activist organizations where he worked that continually problematized his insider/outsider position in a dialectic understanding and practice of identity and difference (Sherif 2001). Fieldwork was conducted openly, even as individuals labelled the first author as a journalist. While this (mis)identification did not occur by those activist organizations with whom he worked, others' perceptions of the fieldworker did not adversely affect interactions, though it did lead to guarded comments at times. To ensure greater comprehension of events, preliminary analyses were regularly discussed with Brazilian colleagues and friends thereby ensuring greater sensitivity to cultural difference. These conversations formed much of the reflexive fieldnotes that accompanied participant observation.

\section{Forced Removals}

Vila Autódromo suffered heavily from evictions in the lead up to the Games. Originally a community of around 600 families, a sustained campaign of removals during the lead up to the Olympics reduced the community to just 20 families through a combination of increasingly generous compensation packages and what one resident described as "psychological terrorism" by City Hall. Many residents who left wanted to return but were not allowed to, and all the residents who eventually remained had their homes destroyed and new homes built, utterly changing the character of the area. The community's fight against eviction gained significant coverage by the international press, with many journalists who visited Rio de Janeiro to report on Olympic preparations making visits to the community. 
Vila Autódromo is the only place in the city where evictions have been caused by mega-events according to Mayor Eduardo Paes. Yet, 22,059 families in total (around 77,206 people) were evicted between 2009 and 2015 across the city of Rio de Janeiro (Comitê Popular da Copa e Olimpíadas do Rio de Janeiro, 2015). Looking at the justifications given for other removals, 4,120 families were evicted across the city specifically for mega-event related development, with many others forced to move due to real estate speculation fuelled by mega-events (ibid.). Mega-events have brought the reality of evictions back to Brazil, and those affected have claimed their rights have been abused (Faulhaber and Azevedo, 2015).

Rio's government committed six violations of Vila Autódromo residents' constitutional right to housing in the lead up to Rio 2016 (Comitê Popular da Copa e Olimpíadas do Rio de Janeiro, 2015: 38-39). These are: (1) lack of information provided to residents, (2) lack of community involvement in upgrading projects, (3) low levels of compensation forcing evictee's further from commercial centres, (4) criminalisation of and refusal to negotiate with community organisations, (5) threats, pressure and coercion, and (6) the use of the justice system as a tool against citizens. One resident of Vila Autódromo, Thais ${ }^{2}$, told a group of visitors from the human rights NGO Amnesty International that the laws around demolitions were not obeyed, in particular water should be sprayed as the demolition occurs, reducing dust. She also outlined one eviction that stood out among the most egregious abuses of state power - a woman's home was demolished while she was at a doctor's appointment only to discover that she was homeless when she returned (see Salvesen, 2015). Alternative housing for her was finally arranged by City Hall a full five months later.

Vila Autódromo residents' resistance to eviction had two key prongs: legal and media. Legal rights were secured in the 1990's when Eduardo Paes (then deputy Mayor for the area) tried to remove the community. In 1994, as a result of campaigning against this eviction attempt, the community won a 99-year lease to the land, which was owned by the State of Rio. In 2004, it was designated an Area of Special Social Interest, which obliged City Hall to provide services such as refuse collection and upgrading projects. Residents used these legal victories to present their situation as a case of human rights abuses as evictions proceeded in the years before the Olympics, using the politics of

rights approach described by Scheingold (2004). Vitoria, who was a prominent media presence, used press interviews to affirm her right to stay in her home. Even when her house was destroyed, she only changed her line of argument slightly, instead insisting on her right to stay in Vila Autódromo. Graffiti scrawled on buildings throughout the community also asserted residents' right to stay, including:

\section{WE ARE POOR, BUT WHY LEAVE. DO WE NOT HAVE THE RIGHT?}

\section{WHY STAY? BECAUSE WE HAVE THE RIGHT!}

COMPLEMENTARY LAW 74 AREA OF SPECIAL SOCIAL INTEREST. WE HAVE THE RIGHT TO LIVE HERE. IT REMAINS TO BE SEEN IF THERE IS MORALITY IN THE JUSTICE SYSTEM OR IF THAT IS WHERE CORRUPTION BEGINS. NOT EVERYONE HAS A PRICE!

Evictions in Vila Autódromo became a highly visible issue during event preparations, heavily covered by foreign journalists who flew in to assess Olympic preparations. Local activist groups, like the Comitê Popular, supported residents by collaborating with them to organise regular events in the community. The groups also included residents in many of their own events that denounced

\footnotetext{
${ }^{2}$ All residents' names are pseudonyms
} 
violations of human rights in the Olympic city. In December 2015, Thais spoke on the panel at the launch of the fourth edition of the Comitê Popular's dossier of human rights abuses, for example (2015). International NGOs also supported the community. Terre des Hommes' campaign Children Win provided significant coverage of the community via the production of an award-winning documentary film, "The Fighter" (Kell and Nizza, 2016). Around 20 workers from Amnesty International's offices around the world visited the community in March 2016 to learn more about the violations of rights there. Rio de Janeiro based NGO Catalytic Communities used its media platform RioOnWatch to provide in-depth, detailed reporting on events there, as well as supporting journalists with information, video, photographs and helping arrange community visits.

\section{Police violence}

Rio's reputation as a violent city was cited as a reason it failed in its bids to host the 2004 and 2012 Olympics Games (Boykoff, 2016, p. 225-227). To remedy this, a collaboration between federal, state and city government began with the laudable aim of permanently removing criminal gangs from Rio's periphery (UPP, n.d.). In essence, this "pacification" programme entails the occupation of favela communities by military police leading to the establishment of a permanent UPP (Police Pacifying Unit) based in the community. These specialised military police units then patrol the communities, often with assault rifles ready to open fire. This was accompanied by a community development initiative known as UPP Social to the policy, providing services in the pacified communities (Rio+Social, n.d.).

The military police's proclivity for violence detailed above is by no means the only problem with pacification. In communities where pacification has been more successful, like Vidigal and Santa Marta, both in the wealthier South Zone of the city, increased safety has driven housing costs have sharply upward, forcing some long-term residents out of their homes. The woeful absence of community development in the implementation of the programme (compared to the stated plan) coupled with the absence of state regulation in favelas means that once a favela has been pacified, market forces drive up rents and other living costs (Cunha, 2015). No steps were taken to ensure that the residents of favelas would be protected from land speculation once pacification increased the value of land in these favelas.

But in these predominantly South Zone favelas, pacification can at least claim some success trafficking gangs have significantly less power, and in some cases no longer operate, in certain favelas. In other favelas, pacification has simply meant shootouts occurring on an almost daily basis. In Complexo do Alemão, a group of favelas in Rio's traditionally poorer North Zone, there were more days with gun battles than without in 2015 . The pacification programme is designed not to provide safety, merely the impression of safety for Olympic visitors (Boykoff, 2016, p. 225-227). This follows a trend with mega-event security where security has become part of the spectacle as ever more advanced security measures are deployed (Boyle and Haggerty, 2009). This spectacle of security plays a dual role - reassuring international visitors while simultaneously impressing the idea of state power on marginalised populations (Cornelissen, 2011).

But this show of force is damaging to the residents who live in favelas, further marginalising residents and harming relations between residents and the state, particularly the police. A survey conducted in the lead up to the Games found that residents of favelas fear the police more than trafficking gangs and urbans militias (Gagne, 2016). As an activist and resident of Complexo do Alemão put it, "we ask for peace, but the police with rifles and tanks is not peace!" (quoted in Robertson, 2016). Policing seems to be the only public policy in favelas like Complexo do Alemão, 
according to a member of the activist group Coletivo Papo Reto (Straight Talk Collective), speaking at a protest in July 2016.

Activists have formed collectives to denounce police violence, such as Coletivo Papo Reto in Complexo do Alemão, Maré Vive (Maré Lives) in Complexo do Maré, and the Fórum de Juventudes (Youth Forum), which works across the entire city. These groups use social media, mostly Facebook, to report on violence and condemn police violence. Unlike activists protesting against forced removals and evictions, these activist groups tend not to emphasise human rights discourse in their statements, only the Fórum de Juventudes even mentions the word "rights" in their Facebook page descriptions. Instead, their focus is on sharing stories of abuses, capturing photographs and videos and using social media as their prime means of communication. This does not mean to say they do not engage in offline protest; Coletivo Papo Reto organised (with community newspaper Voz da Comunidade [Voice of the Community]) an event in the lead up to the Olympics which challenged the "complex situation caused by the Rio 2016 Olympics, where part of the city celebrates while another part bleeds".

Technology, particularly smartphones with cameras, aided these groups in highlighting abuses. In 2015, when police were filmed altering the scene of a killing to make it appear that the youth they had just killed had a weapon, the video was in the national and international press within 12 hours. Apps like Whatsapp, providing free, instant, and secure communication, have made spreading warnings of police operations much easier, with Facebook also playing a similar role. Nós Por Nós (Us By Us), a specially made smartphone app created by the Fórum de Juventudes with support from a range of other groups, allowed residents to provide details of police violence, including photos and videos, anonymously (van Mastrigt and Reist, 2016). The option to contribute anonymously is important, as the resident who filmed the incident of police altering a scene, mentioned above, was reportedly threatened by police afterwards. Other smartphone-based systems to allow residents to report police violence were created by other groups, and Nós Por Nós reported that after just two weeks 40 incidents of police violence had been reported and Rio's public defender's office noted this was helping them react faster to incidents (Calisto and van Mastrigt, 2016).

Major international NGOs such as Amnesty International and Human Rights Watch produced several reports detailing the levels of police violence in Brazil. These groups focussed specifically on human rights abuses, and tended to place police violence at the forefront of their assessments of Brazil, particularly in relation to the 2016 Olympic Games. These NGOs partnered with favela organisations for much of their work, and Amnesty International ran a campaign in the weeks leading up to the Games under the slogan "violence is not a part of this game". RioOnWatch, the media project of Riobased NGO Catalytic Communities, attempted to use the Olympic moment to transform global discourses around favelas in order to bring a lasting policy change by which the state engages with favelas through more than just policing (see Talbot, forthcoming).

Despite this work by Catalytic Communities, the stigmatised reputation of favelas around the world means it was no surprise to see violence as one of the most reported themes in the international media. Violence was covered particularly heavily in the lead up to the Games due to a clear increase in violence in the weeks and months before the Olympics. Some favela residents believed this surge in violence was due to a police offensive, noting similarities to the World Cup - they felt the police were using the period before the mega-event to send a message to traffickers, a warning not to mess with the event. In the weeks before the Games, two of Brazil's mainstream media outlets (Globo and Veja) which traditionally paid little attention to police brutality ran reports critical of the security forces (Briso, 2016, Ritto et al., 2016). 


\section{Conclusions}

Comparing the framing of these issues by activists with that of the media highlights an important discrepancy. Housing issues are not reported as rights issues when activists are specifically drawing that link, whereas police brutality is reported as a rights issue when grassroots activists are not explicitly describing it as such. It seems that killings by police are a much more obvious abuse of human rights than evictions - denying someone their life is about as clear an abuse of their rights as is possible. While The Universal Declaration of Human Rights (United Nations, 1948) asserts that all the listed rights are fundamental, it seems that state killing is treated as a more grievous abuse than others, perhaps due to some of the obfuscation regarding the legal implications of the human right to housing.

A further reason international media may have been more predisposed to describe police brutality in terms of human rights is the work of major, recognised human rights defenders, such as Amnesty International and Human Rights Watch, in highlighting police brutality issues. Both these organisations produce detailed annual reports of the state of human rights around the world, including in Brazil. The detail of these reports provides various easily accessible statistics that can be used by press in compiling articles on security issues in Rio, which were complemented by news stories published on websites. Amnesty published six stories about rights abuses in Rio in 2016 before the Games began yet, in contrast, only published five about the entire country of Ukraine during the same period, despite the civil war raging there.

While activists fighting for housing rights did have some support from international human rights defenders, it was by no means as comprehensive as on the issue of police brutality. Of Amnesty's six news articles on Rio, one was about housing rights while the remaining five were about police violence. As such, international human rights NGOs are crucial in defining human rights issues, given their institutionalised status within the international system of rights (Stammers, 2009). While conversations the first author had with Amnesty staff in Vila Autódromo clearly demonstrated their interest in the case as an abuse of human rights, the NGO's public work remained largely quiet on housing rights issues. This demonstrates the challenge for grassroots activists in contesting the nature of rights. In essence the "profound social change" (Hoover 2015, p. 1095) demanded by recognising housing as a right is disregarded as the institutionalised system of rights sustains the power of the status quo.

As such, grassroots activism in Vila Autódromo served a dual purpose. While residents were of course protesting in their own interest, to remain in the homes they had built for themselves, their activism also had a second dimension: fighting for the recognition of housing as a human right. While this normally remained an implicit part of their activism, at times it came to the fore. An academic speaking at the launch of the Vila Autódromo Popular Plan told the crowd that he had been at a conference in India and heard people say they'd taken inspiration from Vila Autódromo in their own struggles. In this sense, Vila Autódromo became a symbol, and residents like Vitoria embraced that. When a journalist asked what she would want athletes to know about Vila Autódromo, she replied that she wanted people to know what happened here, so that it wouldn't happen again in other cities, so that other people's right to housing would be respected.

Grassroots activists protested against various human rights abuses in Rio in the lead up to the Olympic Games - exacerbated by other mega-events including the 2014 FIFA World Cup and 2007 Pan-American Games. Rights violations were so common that the Comitê Popular were able to release four dossiers of abuses, the final dossier being almost 200 pages in length. Support from major international NGO's helped activists get their criticisms of the Olympic project heard in the 
media, who spread these criticisms all over the world. The IOC's tentative steps towards reform clearly need more work if they are to eliminate human rights abuses at forthcoming Games in Pyongchang, Tokyo, Beijing and beyond.

The issue of police violence was considered an abuse of human rights much more regularly than that of eviction, suggesting that there exists a hierarchy of rights, with some more respected than others. Some rights (such as the right to life) are more fundamental than others, correlating with sustained engagement with issues of police killings by respected human rights defenders, with less engagement of established human rights actors on the issue of housing. As such, activists fighting against removals are often fighting a dual battle - a fight to ensure their own right to remain is respected, and a fight for the full recognition and application of their right to housing as a fundamental human right. The right to housing remains a problematic right, given the inherent critiques of market-based housing provision and the implications for property ownership.

\section{References}

Agamben, G. (1998). Homo Sacer: Sovereign Power and Bare Life. D. Heller-Roazen, transl. Stanford: Stanford University Press.

Amnesty International. (2015). Brazil: 'Trigger happy' Military Police kill hundreds as Rio prepares for Olympic countdown. Retrieved from https://www.amnesty.org/en/latest/news/2015/08/braziltrigger-happy-military-police-kill-hundreds-as-rio-prepares-for-olympic-countdown/

Amnesty International. (2016a). Amnesty International Report 2015/16: The state of the world's human rights. London: Amnesty International.

Amnesty International. (2016b). Brazil on fast-track course to repeat epic World Cup failures during Olympics. Retrieved from https://www.amnesty.org/en/latest/news/2016/06/brazil-on-fast-trackcourse-to-repeat-epic-world-cup-failures-during-olympics/

Arendt, H. (1973). The Origins of Totalitarianism. New York: Harcourt Brace.

Bourke, J. (2011). What It Means To Be Human. London: Virago.

Brown, W. (1995). States of Injury. Power and Freedom in Late Modernity. Princeton: Princeton University Press.

Boykoff, J. (2014). Activism and the Olympics: Dissent at the Games in Vancouver and London. London: Rutgers University Press.

Boykoff, J. (2016). Power Games: A Political History of the Olympics. London: Verso.

Boyle, P. and Haggerty, K. (2009). Spectacular Security: Mega-Events and the Security Complex. International Political Sociology, 3 (3), 257-274.

Briso, C. B. (2016). O adeus de Joselita, mãe de menino morto em Costa Barros [The farewell of Joselita, mother of boy killed is Costa Barros]. O Globo. Retrieved from http://oglobo.globo.com/rio/o-adeus-de-joselita-mae-de-menino-morto-em-costa-barros-19680236

Caldeira, T.P.R. (2000). City of Walls: Crime, Segregation, and Citizenship in São Paolo. Berkeley: University of California Press. 
Calisto, B. and van Mastrigt, J. (2016). Youth forum presents preliminary results of "Nós Por Nós" app to denounce police violence. RioOnWatch. Retrieved from

http://www.rioonwatch.org/?p=28128

Catalytic Communities. (2015). Favelas in the Media: Shifting Public Perception 2009-2014. Retreived from http://catcomm.org/media-analysis-2014/

COHRE (Centre on Housing Rights and Evictions). (2007). Fair Play for Housing Rights: Mega-Events, Olympic Games and Housing Rights. Geneva: COHRE.

Comitê Popular da Copa e Olimpíadas do Rio de Janeiro. (2015). Olimpíada Rio 2016, os jogos da exclusão: Megaeventos e Violações dos Direitos Humanos no Rio de Janeiro [The Rio 2016 Olympics, the exclusion games: megaevents and human rights violations in Rio de Janeiro]. Rio de Janeiro, Comitê Popular da Copa e Olimpíadas do Rio de Janeiro.

Constitução Federal (1988). Retrieved from

http://www.planalto.gov.br/ccivil_03/constituicao/constituicaocompilado.htm

Cornelissen, S. (2011). Mega Event Securitisation in a Third World Setting: Glocal Processes and Ramifications During the 2010 FIFA World Cup. Urban Studies, 48 (15), 3221-3240.

Cunha N. V. (2015). New Conflicts in the Margins of the City: Public Policy in the Favelas of Rio de Janeiro. Seminar in the 'Latin America - the Potential of the Global South?' series, University of Manchester, 18 March 2015.

DaMatta, R. (1984). “On Carnaval, Informality, and Magic: A Point of View from Brazil” Text, Play, Story: The Construction and Reconstruction of Self and Society. E. M. Bruner, ed. Pp. 230-246. Washington DC: American Ethnological Society.

Davis, J., and Thornley A. (2010). "Urban regeneration for the London 2012 Olympics: Issues of land acquisition and legacy" City, Culture, and Society 1(2): 89-98.

Douzinas, C. (2000). The End of Human Rights. Oxford: Hart Publishing.

Earle, L. (2012). From Insurgent to Transgressive Citizenship: Housing, Social Movements and the Politics of Rights in São Paulo. Journal of Latin American Studies, 44 (1), 97-126.

Emerson, R., Fretz, R. and Shaw, L. (2001). Participant Observation and Fieldnotes. In: Atkinson, P., Coffey, A., Delamont, S., Lofland, J. and Lofland, L. (Eds.) Handbook of Ethnography. London: Sage, 352-368.

Fábio, A. C. (2016). Estresse, tabu e hierarquia: por que os policias se matem [Stress, taboo and heirarchy: why police kill themselves]. Nexo Jornal. Retreived from https://www.nexojornal.com.br/expresso/2016/04/21/Estresse-tabu-e-hierarquia-por-que-ospoliciais-se-matam

Faulhaber, L. (2013). Rio maravilha: Práticas, projetos, o intervençönes no território [Wonderful Rio: practices, projects, the interventions in territory]. Niterói: EAU Federal Fluminese University. 
Faulhaber, L. and Azevedo, L. (2015). SMH 2016: Remoções no Rio de Janeiro Olímpico [SMH² 2016: Removals in Olympic Rio de Janeiro]. Rio de Janeiro: Mórula Editorial.

Gagne, D. (2016). Rio favelas fear police more than drug traffickers: survey. Insight Crime. Retreived from http://www.insightcrime.org/news-briefs/rio-brazil-favelas-fear-police-more-than-drugtraffickers-survey

Gold, J. R. and Gold, M. M., eds. (2011). Olympic Cities: City Agendas, Planning, and the World's Games, 1896-2016. New York: Routledge.

Goldstein, D. (2003). Laughter Out of Place: Race, Class, Violence, and Sexuality in a Rio Shantytown. Berkeley: University of California Press.

Hannerz, U. (2004). Foreign News: Exploring the World of Foreign Correspondents. Chicago: University of Chicago Press.

Hobbes, T. (1962) Leviathan. New York: Touchstone Books.

Holston, J. (2008). Insurgent Citizenship: Disjunctions of Democracy and Modernity in Brazil. Princeton: Princeton University Press.

Hoover, J. (2015). The human right to housing and community empowerment: home occupation, eviction defence and community land trusts. Third World Quarterly, 36 (6), 1092-1109.

Human Rights Watch. (2016). Brazil: Extrajudicial executions undercut Rio security. Retreived from https://www.hrw.org/news/2016/07/07/brazil-extrajudicial-executions-undercut-rio-security

Kell, D., and Nizza, C. (2016). The Fighter. Terre des Hommes. Available at http://www.childrenwin.org/the-fighter-my-community-is-being-torn-apart-before-the-rio-2016olympics/

Lenskyj, H. (2008). Olympic Industry Resistance: Challenging Olympic Power and Propaganda. Albany: State University of New York Press.

Larkins, E. R. (2015). The Spectacular Favela: Violence in Modern Brazil. Berkeley: University of California Press.

Paine, T. (1993). The Rights of Man. Everyman Edition, London: J.M. Dent

Perlman, J. (2010). Favela: Four Decades of Living on the Edge in Rio de Janeiro. Oxford: Oxford University Press.

Rawlence, B. (2016). City of Thorns: Nine Lives in the World's Largest Refugee Camp. London: Portobello Books.

Reus-Smit, C. (2001). Human Rights and the Social Construction of Sovereignty. Review of International Studies, 27, 519-538.

Rio+Social. (n.d.). Programa: Rio+Social. [online]. Last accessed 19 June 2015 at: http://www.riomaissocial.org/programa/

${ }^{3}$ SMH stands for Secretaria Municipal de Habitação e Cidadania (Municipal Secretary for Housing and Citizenship). The letters are sprayed on buildings marked for demolitions along with a number - leading some to joke that SMH stands for Sai do Morro Hoje (leave the favela today). 
Ritto, C., Sampaio, J., Leitão, L., Bustamente, L., Vieira, M. C., Trindade, R., ... Prado, T. (2016). O que acontece durante 48 horas no Rio de Janeiro. Veja. Retreived from

http://veja.abril.com.br/complemento/brasil/o-que-acontece-durante-48-horas-no-rio-de-janeiro/

Robertson, C. (2016). A close look at the international awards and recognition of the Olympic city.

RioOnWatch. Retreived from http://www.rioonwatch.org/?p=28309

Salvesen, S (2015). Dona Mariza Left Homeless After Eviction in Vila Autódromo Next Door to

\#Rio2016 Olympics. RioOnWatch. Retrieved from http://www.rioonwatch.org/?p=25558

Scheingold, S. (2004). The Politics of Rights: Lawyers, Public Policy and Political Change. New Haven: Yale University Press.

Scheper-Hughes, N. (1993). Death without Weeping: The Violence of Everyday Life in Brazil. Berkeley: University of California Press.

Sherif, B. (2001). The ambiguity of boundaries in the Fieldwork Experience: Establishing Rapport and Negotiating Insider/Outsider Status. Qualitative Inquiry, 7 (4), 436-447.

Stammers, N. (2009). Human Rights and Social Movements. London: Pluto Press.

Talbot, A (forthcoming). Transforming policy through discourse intervention: RioOnWatch, favelas, and the 2016 Olympic Games. In: Carter, T., Burdsey, D., and Doidge, M. (eds.) Transforming Sport. London: Routledge.

United Nations (1948). Universal Declaration of Human Rights. Retreived from http://www.un.org/en/universal-declaration-human-rights/

UPP (n.d.). UPP - Unidade de Polícia Pacificadora: About. [online]. Last accessed 19 June 2015 at: http://www.upprj.com/index.php/o_que_e_upp_us

van Mastrigt, J. and Reist, S. (2016). Youth Forum launches "Nós Por Nós" application to denounce police violence. RioOnWatch. Retrieved from http://www.rioonwatch.org/?p=27670

Vijay, A. (2015). "After the pop-up games: London's never-ending regeneration" Environment Planning D 33(3): 425-443.

Whannel, G. (1992). Fields in Vision: Television Sport and Cultural Transformation. London: Routledge. 